\title{
EMPLOYERS, UNIONS, AND AMERICAN EXCEP- TIONALISM: PRE-WORLD WAR I OPEN SHOPS IN THE MACHINE TRADES IN COMPARATIVE PER- SPECTIVE*
}

SUMmaRY: In comparative perspective, U.S. employers have been unusually hostile to unions. Their labor policies varied from one time and industry to another, however, in defiance of familiar interpretations of American "exceptionalism". It is argued that before World War I, open shops and trade agreements represented different solutions for common labor problems. The timing of changes in technology and industrial structure relative to union growth determined which strategy would be more attractive to employers. This argument is developed by comparing one open shop industry (the machine trades) with its British counterpart and, more briefly, with some U.S. industries where trade agreements prevailed.

National Metal Trades Association President Caldwell affirmed to convention delegates in 1912 a view of trade unionism widely shared by U.S. employers: "So long as American labor unions, as part of their fundamental purposes, insist upon the restriction of output, the limitation of apprentices, the minimum wage, and the closed shop, and so long as they seek to shorten the workday [and] countenance violence [. . .] just so long will they be opposed by our Association firmly and with unrelaxed vigilance". ${ }^{1}$ In principle, "open shop" employers neither favored nor discriminated against unionists in hiring and firing; they merely insisted on negotiating solely with their own employees. In practice, managers denied unionists jobs as well as collective bargaining rights.

It is often argued that U.S. employers' hostility to labor organization was extreme in comparison to their European counterparts. Belligerant open shop practices, in turn, are frequently invoked in explaining the exceptional

* An earlier version of this article was presented at the Annual Meeting of the American Sociological Association, August 17, 1987. The paper has benefited from the comments of Katherine Mooney.

${ }^{1}$ Quoted by Clarence E. Bonnett, Employers' Associations in the United States: A Study of Typical Associations (New York, 1922), p. 103. 
weakness of American unions. ${ }^{2}$ The following article has no quarrel with these conclusions. Instead, it seeks to refine explanations for the labor policies of U.S. employers by placing those policies in their historical and comparative context. In doing so, questions will also be raised about the application of common theories of American "exceptionalism" to industrial relations.

The specific goals of this article are, first, to show that the development of open shop policies in the U.S. during the early 20th century was closely related to a historical transformation in many American industries. Employers' efforts to install new machinery, dilute labor, and tighten control over production threatened the position of craftsmen. Open shop practices represented one strategy for resolving the ensuing conflicts in management's favor. Second, it will be argued that the dominance of open shop principles was by no means assured at this time. The period featured considerable debate and experimentation among employers. Influential business spokesmen, notably members of the National Civic Federation, advocated a different strategy for solving conflict between labor and capital: union-management cooperation through formal trade agreements. Employers in a number of industries, moreover, actually adopted such schemes for varying lengths of time.

The third goal is to explain the resort to open shop strategies by most but not all - U.S. employers. Labor policies, it is argued, reflected underlying economic conditions in particular industries more than they represented any overall national character. Where changes in technology and market structure were rapid and, more importantly, occurred before the consolidation of trade unionism, employers had less to gain from collective bargaining and less to lose from anti-union activities. Union recognition and negotiation were less attractive to employers when technological changes reduced their dependence on skilled unionists; when managers could reduce competitive pressures without relying on industry-wide trade agreements; and when unions were still too weak to be useful allies in managing the workforce. The same conditions made skilled workers and their unions easier to fight. Timing made a difference. Neither the state of unions (strong or weak) stressed by Weinstein ${ }^{3}$ nor the state of conflicts

2 James Holt, "Trade Unionism in the British and U.S. Steel Industries, 1880-1914", Labor History, XVIII (1977), pp. 5-35; Bernard Elbaum and Frank Wilkinson, "Industrial Relations and Uneven Development: A Comparative Study of the American and British Steel Industries", Cambridge Journal of Economics, III (1979), pp. 275-303; Michael Shalev and Walter Korpi, "Working Class Mobilization and American Exceptionalism", Economic and Industrial Democracy, I (1980), pp. 46-47; Henry Phelps Brown, The Origins of Trade Union Power (Oxford, 1983), pp. 197, 203-207; and Larry Griffin et al., "Capitalist Resistance to the Organization of Labor Before the New Deal: Why? How? Success?", American Sociological Review, LI (1986), pp. 146-167.

${ }^{3}$ James Weinstein, The Corporate Ideal in the Liberal State: 1900-1918 (Boston, 1968), p. 38. 
over craft controls (truce or war) emphasized by Montgomery ${ }^{4}$ adequately explain the adoption of conciliatory as against combative policies toward unions in different industries. The relative timing and pace of changes in technology and unionization better account for why management in some industries endorsed collective bargaining while in others they enforced open shops.

These arguments are developed first and most fully through a comparison of the 1897-1898 British engineering lockout and the 1900-1901 U.S. machinists' strikes. This is an instructive case. It demonstrates the labor problems facing managers during the transition from craft production to modern manufacture - problems shared by British and American firms. It also shows that employers in both countries actively considered alternative strategies for meeting those problems. Finally, the case reveals outcomes which in the end were typical of industrial relations in each country as a whole: collective bargaining and strong unions in Britain, open shops and weak unions in the U.S. The explanations offered for outcomes in the machine trades are then applied briefly to other cases in the U.S.. It will be shown that where the relative timing of changes in technology, market structure, and unionization departed from American norms, so did employers' labor policies.

The use of comparisons among U.S. cases is designed to develop a more rigorous account of early industrial relations trends. Explanations for typical cross-national differences should also fit contrasts between industries within each country. These explanations are not offered as timeless generalizations, however. They are tied to a specific period in the development of manufacturing techniques and to a period before open shop principles became business orthodoxy. The following account, accordingly, does not apply either to industries lacking craft traditions (such as dockyards) or to later conflicts over unionization (notably the rise of the $\mathrm{CIO}$ ).

Greater attention to inter-industry comparisons has another, more polemical purpose: to raise awkward questions for common theories of American "exceptionalism". Most scholarly work on the peculiarities of class formation in the United States focuses on labor's limited and short-lived commitments to independent political organization and socialist ideology. ${ }^{5}$ Some of the standard explanations for working-class political behavior,

\footnotetext{
${ }^{4}$ David Montgomery, Workers' Control in America: Studies in the History of Work, Technology, and Labor Struggles (Cambridge, 1979), p. 63.

${ }^{5}$ For reviews of the literature on why socialism has been so marginal in the U.S., see Ira Katznelson, City Trenches: Urban Politics and the Patterning of Class in the United States (New York, 1981), ch. 1; Jerome Karabel, "The Reasons Why", New York Review of Books, XXVI, no 1 (1979), pp. 22-27; and Seymour Martin Lipset, "Why No Socialism in the United States?", in S. Bialer and S. Sluzar (eds), Sources of Contemporary Radicalism (Boulder, Colorado, 1977), pp. 31-149.
} 
however, have also been applied to industrial life. ${ }^{6}$ For example, in explaining the reluctance of workers to join and employers to recognize unions Lipset invokes a familiar culprit in accounts of working-class politics: American individualism. Peculiar political and religious traditions, he argues, made employers and workers alike eschew collectivism in industrial relations. Yet internal comparisons highlight important variations in employer policies and union strength within the U.S. Causal theories pitched at the national level cannot accomodate these variations. ${ }^{7}$ One must instead root explanations for turn-of-the-century employer practices in the histories of particular industries.

\section{The Labor Process and Industrial Relations in the Machine Trades, 1898-1901}

To argue that employer policies toward unions should be viewed against the backdrop of changes in the labor process is hardly novel. A familiar theme in historical studies of the American workplace emphasizes that production practices in many 19th century industries were controlled more by craftsmen than by owners. At different times in different trades, the controls exercised and the privileges enjoyed by skilled men became serious obstacles to employers' efforts to rationalize manufacturing techniques. Open shop drives represented attacks on those craft controls that blocked the exploitation of new technologies and managerial methods. ${ }^{8}$

The open shop drive did aim to overcome craft resistance to new forms of production. Union-busting was not the only strategy for consolidating

${ }^{6}$ Examples include Seymour Martin Lipset,"North American Labor Movements: A Comparative Perspective", in S.M.Lipset(ed.), Unions in Transition: Entering the Second Century (San Francisco, 1986) and Shalev and Korpi, "Working Class Mobilization and American Exceptionalism".

7 For similar criticism of generalized theories of American working-class politics, see Aristide Zolberg, "How Many Exceptionalisms?", in Ira Katznelson and Aristide Zolberg (eds), Working-Class Formation: Nineteenth-Century Patterns in Western Europe and the United States (Princeton, 1986), pp. 397-455; and Gary Marks, Unions in Politics: The Comparative Development of Unions in the United States, Britain, and Germany in the 19th and Early 20th Centuries, ms. of forthcoming book, ch. 6 .

${ }^{8}$ Bruno Ramirez, When Workers Fight: The Politics of Industrial Relations in the Progressive Era, 1898-1916 (Westport, Connecticut, 1978), pp. 87-97; a recent restatement is Griffin et al., "Capitalist Resistance to the Organization of Labor Before the New Deal", pp. 149-151. For particular cases see David Brody, Steelworkers in America: The Nonunion Era (New York, 1960), chs 1-3; and Katherine Stone, "The Origins of Job Structures in the Steel Industry", Review of Radical Political Economy, VI (1974), pp. 61-97, on steel; Irwin Yellowitz, "Skilled Workers and Mechanization: The Lasters in the 1890s", Labor History, XVIII (1977), pp. 197-213, on shoes; and Stephen Meyer III, The Five Dollar Day: Labor Management and Social Control in the Ford Motor Company, 1908-1921 (Albany, New York, 1981) and David Gartman, Auto Slavery: The Labor Process in the American Automobile Industry, 1897-1950 (New Brunswick, New Jersey, 1986), chs 2-3, 8, on autos. 
management control, however. Business and labor leaders belonging to the National Civic Federation (founded in 1900) advocated a different tact. They urged employers to recognize unions and accept collective bargaining as a way to stabilize industrial relations and encourage moderation on the part of union officials. Labor organizations would receive increased legitimacy, influence, and membership. In exchange, union leaders would respect management rights and discipline unruly members. NCF spokesmen not only put trade agreements on the national agenda for industrial relations reform; they also played active roles in arranging these schemes in such industries as molding, coal mining, newspaper publishing, brewing, and garment making. ${ }^{9}$ That open shops were not the inevitable outcome of conflicts over workshop control is also suggested by comparisons with Britain. British employers sought similar changes in shop practices as did their American counterparts and confronted no less recalcitrant craftsmen. But they often chose to recognize unions, insisting in return on trade agreements which ratified managerial goals. What led employers in the two countries and in different U.S. industries to their respective labor policies?

A good place to start in developing an answer is the machine trades. In both countries, the problems raised by industrial change and craft restrictions were clear and led to national confrontations. The initial resolutions of these disputes also took identical forms: American as well as British employer associations negotiated industry-wide agreements under which union officials promised to respect management's need for flexibility and order at work. American employers soon abrogated their agreement and adopted the more familiar open shop principles. That they followed an apparently un-American policy even briefly, however, indicates that explanations for the divergence in industrial relations cannot rely on the enduring dispositions of national character.

During the late $1890 \mathrm{~s}$, the efforts of machine trades employers to reduce labor costs and increase output and order in their shops sharpened conflicts with machine shop craftsmen (engineers in Britain and machinists in the U.S.). New machinery and subdivided production tasks challenged craftsmen's job controls and economic privileges. Wage incentive schemes threatened collective bargaining and customary standards for a fair day's work. And closer supervision and tighter control over manufacturing prac-

9 Weinstein, The Corporate Ideal in the Liberal State, ch. 1; and Ramirez, When Workers Fight, ch. 4. 
tices attacked the autonomy and judgment which skilled men traditionally exercised and valued highly. ${ }^{10}$

On a day-to-day basis, resistance to production rationalization presented employers with three specific problems. ${ }^{11}$ First, union work rules restricted management flexibility in exploiting new technological opportunities and product markets. Members of the Amalgamated Society of Engineers (ASE) and the International Association of Machinists (IAM) sought to enforce apprenticeship regulations, insisted that work previously done by fully qualified men continue to be so, and flatly rejected the introduction of payment by results. Second, such rules were by no means uniform. Local union lodges retained responsibility for the details and enforcement of work rules: accordingly, these differed from one district to another. Even within the same city, tactics varied with the strength and politics of individual shop committees and stewards. Local autonomy also had a strategic value. By concentrating union resources on single firms or cities, the IAM and ASE maximized their chances of victory and discouraged the spread of objectionable management practices. The result was to put some manufacturers at a competitive disadvantage. Third, in defending local work rules metal workers tended to walk out promptly and seek union sanction later. Employers thus faced frequent strikes on very short notice.

These were problems for unions leaders as well. The national executives of the ASE and the IAM were more interested than their constituents in trading work rules for economic and organizational consessions, and they saw their unions' finances, reputation, and constitutional authority as jeopardized by hasty strikes and ill-considered local policies. ${ }^{12}$

In July, 1897, British employers' efforts to combat the problems of restrictive work rules and irregular strikes culminated in a nation-wide lockout of ASE members which would eventually involve 700 firms and 47,500 workers. ${ }^{13}$ The lockout's organizer, the Engineering Employers'

${ }^{10}$ For Britain, see James B. Jefferys, The Story of the Engineers, 1800-1945 (London, 1945), pp. 55-58, 122-132; James Hinton, The First Shop Stewards' Movement (London, 1973), pp. 58-62. For the U.S., see William H. Buckler, "The Minimum Wage in the Machinists' Union", in Jacob Hollander and George Barnett (eds), Studies in American Trade Unionism (New York, 1907); Fred H. Colvin, 60 Years with Men and Machines (New York, 1947), pp. 43-45; and Montgomery, Workers' Control in America, chs 1 and 5.

${ }^{11}$ On Britain, see Jefferys, The Story of the Engineers, pp. 91-109, 139-142; Hinton, The First Shop Stewards' Movement, Introduction and pp. 58-61, 79; Keith Burgess, The Origins of British Industrial Relations: The Nineteenth Century Experience (London, 1975), pp. 35-56. On the U.S., see Buckler, "The Minimum Wage in the Machinists' Union", pp. 137-138; Mark Perlman, The Machinists: A New Study in American Trade Unionism (Cambridge, Mass., 1960), pp. 11, 151-152, 303; and Montgomery, Workers' Control in America, pp. 15-18.

12 Jefferys, The Story of the Engineers, pp. 140-142; Machinists' Monthly Journal, January 1891, p. 107; and Perlman, The Machinists, p. 9.

${ }_{13}$ On the lockout, see Jefferys, The Story of the Engineers, pp. 143-149; R.O. Clarke, "The Dispute in the Engineering Industry, 1897-1898", Economica, new series, XXIV (1957), pp. 
Federation (EEF), was itself founded in response to local strikes over work rules, and employers explicitly justified the lockout on the grounds of protecting management rights. By organizing on an industry-wide basis and shifting the battle from a local to national scale, moreover, the EEF aimed to end local variations in union policies and combat the ASE's tactic of picking off employers one by one.

These goals are clear in the Terms of Agreement imposed on a prostrate union in January, 1898. In that agreement, employers claimed the right to introduce piecework and to select, train, employ, and pay workmen as they saw fit. Moreover, these were declared to be non-negotiable principles governing the operation of the engineering industry as a whole. Despite sharp disagreements among employers, however, the EEF chose not to smash the union but to use it for their own purposes. The Terms did represent a national agreement between employers and union representatives and required strong union leadership to enforce its provisions on the rank and file. Unions were also necessary for the employers' third goal: to control strikes. The Terms included an industry-wide grievance procedure under which disputes not settled in the shop would be discussed in local and, if necessary, national conferences. Pending an outcome, there were to be no strikes. Clearly, union discipline was indispensable.

This scheme was not entirely unattractive to ASE leaders. In return for concessions on work rules, they received some contractual protections for union activists and greater authority for themselves in union-management negotiations. The grievance procedure also appeared to be a more civilized and less costly method for resolving disputes than were strikes. ${ }^{14}$

Beginning in March, 1900, a similar battle was fought in the U.S. Five thousand machinists in Chicago, 400 in Columbus, 300 in Paterson, and similar numbers in Cleveland, Detroit, and Philadelphia struck for a ninehour day, union recognition, machinists only on "machinists"" work, seniority and apprenticeship rules, and the recognition of shop committees. ${ }^{15}$ The strikes explicitly challenged management's unfettered control of the workplace. They reveal as well the other problems facing employers. Demands were formulated locally, varying from one strike center to another, and IAM leaders were unable to limit the number of machinists walking out.

The newly formed National Metal Trades Association (NMTA) quickly assumed leadership on the employers' side. Their concerns were clear.

128-137; and H.A. Clegg et al., A History of British Trade Unions Since 1889 (London, 1964), pp. 161-167.

${ }_{14}$ Amalgamated Engineers' Monthly Journal, June 1908, p. 12; and Jefferys, The Story of the Engineers, p. 159.

${ }^{15}$ See U.S. Industrial Commission, Report (Washington, D.C., 1901-1902), v. 8; Perlman, The Machinists, pp. 25-27; and Montgomery, Workers' Control in America, pp. 49-52. 
Although willing to concede the nine-hour day, they refused to accept the restrictions on their authority demanded by machinists. Nor were NMTA leaders willing to settle the strikes on a purely local basis. Employer representatives declined to negotiate with the IAM's Chicago District Lodge because it "does not have a correct knowledge of conditions as they affect the industry at large . . .." "But", the NMTA temporized, "we will recognize your national union through our national association", thus ensuring that "practically the same conditions of labor shall prevail in all the different sections." 16 Lastly, the NMTA sought IAM support in limiting local strike action and would not continue negotiations until union leaders demonstrated their power to call off outstanding strikes throughout the country. ${ }^{17}$

Such concerns were formally embodied in the Murray Hill Agreement which followed the strike. Under the Agreement, IAM leaders abandoned local demands for the closed shop, seniority rights, and shop committee recognition and pledged not to place "restrictions upon the management or production of the shop." In exchange, the NMTA promised the nine-hour day, effective in May, 1901. The Murray Hill Agreement also established a grievance procedure similar to the one in British engineering, replacing local autonomy with uniform national policies and negotiations and proscribing strikes until the completion of central conferences. NMTA leaders invoked the prestige and industrial relations philosophy of the National Civic Federation in urging recalcitrant employers to accept the Agreement. ${ }^{18}$ Union leaders also applauded the pact. Concessions on work rules were justified by union recognition and the nine-hour day, while the disputes procedure protected union finances. As a Machinists' Monthly Journal editorial put it, "If this idea - the board of arbitration - is carried out in a spirit of fairness and equity [. . .] there need never be any more strikes or lockouts, as far as the machinists are concerned." 19

The Murray Hill Agreement appeared to meet the needs both of employers desiring order and IAM leaders eager for recognition. Within a year, however, the Agreement collapsed. Efforts by the IAM to secure a pay hike to compensate for the scheduled reduction in hours failed. A nation-wide strike for the nine-hour day and corresponding wage increases followed in May, 1901. Many NMTA members were affected. Citing this breach of the Agreement, the employers' association withdrew from the pact. It seems clear, though, that the NMTA had decided to break with the Murray Hill Agreement before the strike. Employers insisted that requests for wage increases be handled according to the procedure: first at the level of the

${ }^{16}$ U.S. Industrial Commission, Report, v. 8, pp. 10, xxx.

17 U.S. Industrial Commission, Report, v. 8, pp. viii, 10-11, 19, 30. 513-514.

${ }_{18}$ Montgomery, Workers' Control in America, p. 52.

19 Machinists' Monthly Journal, August 1900, p. 255. 
individual firm, and only later in national conference, and on a case-by-case basis. This was hardly agreeable to the IAM. More importantly, even before negotiations broke down, the NMTA's Administrative Council had instructed its members that "no further concessions should be granted to the Machinists' Union". ${ }^{20}$

NMTA spokesmen justified their withdrawal from the Murray Hill Agreement on the grounds that it had not, after all, solved their problems. Machinists continued to insist on craft restrictions and to strike on short notice and contrary to constitutional procedures. ${ }^{21}$ In other words, union leaders simply could not control their own members. These considerations were all the more disturbing to employers given the rapid increase in union strength under the Agreement - from 22,500 members in 1900 to 32,500 a year later. ${ }^{22}$ NMTA firms viewed these developments as ominous: "the foothold gained in the shops by the unions, under the operation of the [. . . ] agreement, had resulted in the introduction of practices which were subversive of discipline and detrimental to the interests of employers. [. . .] These facts being made clear [. . ] a determination to free themselves absolutely from union control grew with irresistable strength., ${ }^{23}$

The alternative to Murray Hill was the open shop. Management control, the NMTA now claimed, demanded the exclusion of unions from the shops. The Association's 1901 Declaration of Principles asserted employers' "full discretion to designate the men we consider competent to perform the work and to determine the conditions under which that work shall be prosecuted". The EEF claimed no less authority, but it worked with the ASE to codify those powers. The NMTA preferred to ensure its ascendancy by victimizing and blacklisting unionists, employing labor spies, and contesting union interests in state and federal courts and legislatures. ${ }^{24}$ As for fighting strikes, while the EEF enlisted the disciplinary aid of ASE officials, the NMTA offered its full resources to besieged employers - financial aid, legal advice, and NMTA-organized strikebreakers and private guards. Such assistance was not available to members who negotiated with or made concessions to unions.

\footnotetext{
${ }^{20}$ Iron Age, May 16, 1901, p. 49. See also U.S. Industrial Commission, Report, v. 17, pp. 357-359; and Montgomery, Workers' Control in America, pp. 54-57.

${ }_{21}$ U.S. Industrial Commission, Report, v. 8, pp. 513-514, and v. 17, pp. XCIV, 359.

22 Iron Age, June 6, 1901, p. 23; and Perlman, The Machinists, p. 206.

${ }^{23}$ Iron Age, June 6, 1901, p. 23.

${ }^{24}$ Machinists' Monthly Journal, August 1903, pp. 719-720; and Bonnett, Employers' Associations in the United States, pp. 26, 112, 119-121.
} 


\section{Sources of Employer Policies}

The Murray Hill Agreement did not live up to employers' expectations: IAM leaders could not prevent members from imposing craft restrictions or striking in breach of the arbitration procedure. But national officials of the ASE were perhaps even less successful in this regard, and still the EEF clung to the Terms. Why did American employers abandon the Murray Hill Agreement, while the Terms endured? The most important reasons for this divergence involve contrasts in the pace of technological change and trade union growth and differences in industrial structure. ${ }^{25}$ These contrasts shaped employer choices in two ways. First, they meant that American managers had less to gain from trade agreements, and less to lose from abandoning them, than their British counterparts. Second, they provided the economic base for broader industrial traditions, making open shops in the U.S. and trade agreements in Britain congenial as well as practical.

Compared to the British engineering industry, manufacturing practices in late 19th century American metal working were characterized by standardized output, an extensive division of labor, and the use of more automatic, special purpose machinery. ${ }^{26}$ Particularly in the newer sectors devoted to consumer goods (sewing machines, firearms, bicycles), market conditions made it profitable to invest in specialized equipment capable of producing interchangeable parts on a large scale. Large batch production with semi-automatic machinery also made it possible to use workers of narrower skills (and lower pay) in place of broadly trained craftsmen. The success of this "American" system of manufacturing in new metal working industries led to its adoption, so far as possible, even in more traditional sectors like machine tool manufacture.

How did production techniques shape employers' labor policies? The greater progress of technological change made craft restrictions (e.g., the insistence that certain jobs be performed only by skilled men) more irksome and decreased American manufacturers' reliance on skilled unionists. As a result, U.S. employers had both greater interest in attacking union controls at work and found it easier to do so - less experienced workers could be quickly trained to take the place of striking craftsmen. Many of these changes in production practices were firmly in place before the IAM

${ }^{25}$ For other discussions of the importance for labor relations of the relative timing of technological change and union development, see Ronald Dore, British Factory - Japanese Factory: The Origins of National Diversity in Industrial Relations (Berkeley, 1973), chs 14-15; and Michael Burawoy, "The Anthropology of Industrial work", Annual Review of Anthropology, VII (1979), pp. 257-259.

${ }^{26}$ H.F.L. Orcutt, "Machine Shop Management in Europe and America", Engineering Magazine, XVI (1899), pp. 552-553, 703-707; H. J. Habakkuk, American and British Technology in the Nineteenth Century (Cambridge, 1967), pp. 105-106, 151, 170-171, 202-203; and S.B. Saul, "The Engineering Industry", in Derek H. Aldcroft (ed.), The Development of British Industry and Foreign Competition, 1875-1914 (London, 1968), pp. 231, 235. 
(founded in 1888) was securely established. Since the IAM represented relatively few skilled men $^{27}$ the union was of less potential value for helping employers maintain control and manage their workforce. And the IAM's comparative weakness also made it easier to fight than the ASE. Union growth under the Murray Hill Agreement would only have made the contest more difficult.

Advanced production methods and weak unions in the U.S. thus minimized the attractions of trade agreements as a means for consolidating management authority and avoiding disruption. Collective bargaining still might have been useful for standardizing labor costs and limiting competition. This was a less pressing concern in the U.S., however. With capital more concentrated and firms more specialized in narrow product lines (few machine tool manufacturers, for example, competed in any one line), American employers had less need for unions to moderate competitive inequalities among shops and cities. Again, timing was crucial. Even had U.S. employers sought to further stabilize wages and working conditions, they could not rely on the IAM to achieve this goal. Machinists remained sparsely organized, and conciliatory employers would have confronted firms which still enjoyed the benefits of open shops. Members of the EEF, by contrast, had a greater interest in limiting competition, and, because skilled workers were more widely organized, employers also had in unions an effective means with which to pursue that interest. ${ }^{28}$

These differences were of long standing and supported contrasting industrial relations traditions that influenced employer choices during the crises of 1897-8 and 1900-1. During the second half of the 19th century, British engineering experienced a slow but steady growth in its exports of heavy machinery whose manufacture required skilled men. Export demand could be met through an expansion of employment within the technical status quo, avoiding confrontations over established work practices. ${ }^{29}$ By 1897 ,

27 The IAM enrolled about $11 \%$ of machinists in 1900 , as compared to perhaps $50 \%$ in the ASE and other craft societies. See Montgomery, Workers' Control in America, p. 63; Charles More, "Skill and the Survival of Apprenticeship", in Stephen Wood (ed.), The Degradation of Work? Skill, Deskilling, and the Labour Process (London, 1982), p. 112; and George Sayers Bain and Robert Price, Profiles of Union Growth (Oxford, 1980), p. 50.

${ }_{28}$ Orcutt, "Machine Shop Management in Europe and the United States", pp. 551-554; Great Britain Board of Trade, Report of the Departmental Committee Appointed by the Board of Trade to Consider the Position of the Engineering Trades After the War (London, 1918), p. 7; and Habakkuk, American and British Technology in the Nineteenth Century, p. 219.

${ }_{29}$ Habakkuk, American and British Technology in the Nineteenth Century, p. 215; Burgess, The Origins of British Industrial Relations, pp. 3-4; and Jonathan Zeitlin, "The Labour Strategies of British Engineering Employers, 1890-1922", in Howard Gospel and Craig Littler (eds), Managerial Strategies and Industrial Relations: An Historical and Comparative Study (London, 1983), pp. 25-54. 
British engineering thus enjoyed a tradition of collective bargaining which extended back over forty years. When new technological opportunities intensified conflict in the 1890s and led to the nation-wide lockout of 1897 , most employers saw the dispute as an opportunity to force union compliance with management needs rather than as a chance to smash the union. Sustained economic growth in the industry after 1898 enabled employers to accept the failings of the Terms of Agreement and made a general confrontation with craft unions unattractive.

The timing of technological change and union development had different consequences in the U.S. machine trades. Economic growth during the 1870 s and 1880 s was rapid, it was led by the development of new product markets, and it occurred amid a scarcity of skilled labor. Employers responded with labor-saving technologies and shop reorganization rather than expanding the scope of traditional manufacturing practices ${ }^{30}$ By the time the IAM began pressing for agreements on work rules and wage rates, the strategic position of skilled men at work had already eroded. In this context, union recognition and collective bargaining seemed to endanger both employers' right to manage and the success of their businesses. Moreover, quite different industrial relations practices had become customary, especially in the northeast where machinists were most weakly organized and production methods most progressive. Here employers negotiated pay and working conditions with their own employees, if possible on an individual basis. No legacy of collective bargaining existed to sustain the Murray Hill Agreement in the face of widespread disputes over wages in 1901. This explanation for why U.S. employers rejected trade agreements also accounts for why they briefly embraced them. The storm center of the 1900 dispute was Chicago, the one American city which could rival Britain for strong union organization and a history of collective bargaining. Here employer support for trade agreements made sense, and indeed collective bargaining survived in Chicago even after the demise of Murray Hill. ${ }^{31}$

\section{Evidence from Internal Comparisons}

This account of industrial relations in the machine trades may be more widely applicable. In a broad range of American industries, the shift from craft production to modern manufacture began before the emergence of stable trade unionism in the late $1800 \mathrm{~s}$. In Britain, by contrast, craft unions established themselves in numerous trades during the third quarter of the 19th century; technological and managerial challenges to craft control at work occurred more slowly and came later. ${ }^{32}$ But perhaps observed differ-

\footnotetext{
${ }^{30}$ Montgomery, Workers' Control in America, p. 48.

${ }^{31}$ Montgomery, Workers' Control in America, pp. 49, 56-58.

${ }^{32}$ Habakkuk, American and British Technology in the Nineteenth Century, documents many of these differences, whatever the merits of his explanation for them. See also Phelps Brown, The Origins of Trade Union Power, pp. 204-206.
} 
ences between British and American industrial relations are the product of distinctive national cultures, political histories, or ethnic compositions rather than contrasts in the timing of industrial change? Internal comparisons suggest not. Where conditions in the U.S. departed from national norms, so did industrial relations.

The machine trades themselves provide one example. The bespoke character of American railroad repair shop work made employers in this sector far more dependent on skilled labor than their counterparts elsewhere in the industry. And here not only were labor policies more conciliatory and unions stronger; in addition, employers pursued strategies typical of British engineering. Railroad management preferred to deal with union leaders rather than with shop-floor representatives, and agreements with unions typically provided for the arbitration of local disputes by national officials. ${ }^{33}$ In England, Coventry's local economy at the end of the century was dominated by newer products associated with more advanced manufacturing techniques - bicycles and automobiles. These industries had developed in the absence of local traditions of engineering trade unionism. ${ }^{34}$ Such "American" conditions had, by British standards, "American" consequences: managers resisted collective bargaining and frequently victimized union activists. Unions gained strength and recognition after 1907, when most major local employers joined the Engineering Employers' Federation and began to follow its labor policies. Yet in the $1920 \mathrm{~s}$, a nation-wide counteroffensive against workplace unionism was pursued with special enthusiasm and exceptional success in Coventry. ${ }^{35}$

Other departures from "typical" patterns of industrial relations in the U.S. also correspond to atypical economic circumstances. In both printing and construction, localized and variable product markets made large-batch production techniques inappropriate. Continued reliance on skilled labor and the resulting opportunity for craft unions to establish themselves raised the costs of open shop policies. Employers instead accepted collective bargaining and even relied on union representatives for help in hiring and workplace discipline - policies which, in turn, favored further union growth..$^{36}$ The International Typographical Union, for example, had secured recognition from most newspaper printing employers by the late 19th

${ }^{33}$ Colvin, 60 Years with Men and Machines, p. 95; Perlman, The Machinists, p. 29; and Montgomery, Workers' Control in America, p. 63.

${ }^{34}$ F.W. Carr, "Engineering Workers and the Rise of Labour in Coventry, 1914-1939" (Ph.D., University of Warwick, 1978), pp. 10, 107.

${ }_{35}$ F.W. Carr, "Engineering Workers and the Rise of Labour in Coventry", pp. 40, 48, 233-234, 246, 258.

${ }^{36}$ Robert Max Jackson, The Formation of Craft Labor Markets (Orlando, Florida, 1984), chs 7-13; and James R. Green, The World of the Worker: Labor in Twentieth Century America (New York, 1980), pp. 34-39. 
century - before the introduction of linotype machines in the 1890s. Some firms did initially attempt to substitute less skilled workers for fully qualified printers on the new equipment. Powerful opposition from the ITU, however, won agreements stipulating that only apprenticed men (in effect, ITU members) could operate linotype machines. ${ }^{37}$ By 1920 , union density among printers stood at $50 \%,{ }^{38}$ far above the national average of $17 \%$ and rivaling the level of organization achieved by British printers $(58 \%$ in 1921. $)^{39}$

In the building trades, the labor process and market conditions both favored cooperation between employers and unions. On-site construction of unstandardized buildings preserved the need for craft skills through the 19th century. Erecting buildings also required a precisely timed coordination of craftsmen of different trades, making contractors unusually vulnerable to strikes by strategic workers. Finally, the industry's small firms and intense competition in local markets forced contractors to depend on unions for training and recruiting craftsmen and for standardizing labor costs. Under these conditions, the open shop National Builders' Association collapsed in 1899 for want of members. Local Builders' Associations and Building Trades Councils in most major cities worked together under trade agreements which regulated employment, fixed wages, and maintained closed shops. By the time building methods began to change in the early 1900s (erecting skyscrapers involved larger construction firms and more standardized building materials and methods), unions had become indispensable for employers and workers alike..$^{40}$ After 1902, while other AFL unions were retreating before the open shop drive, the United Brotherhood of Carpenters and Joiners grew (by amalgamation as well as recruitment) from 68,000 in 1902 to 244,000 in 1912 . Here too, union density ( $50 \%$ in 1920$)$ was well above the notional average, and in 1935 ,

\footnotetext{
${ }^{37}$ Seymour Martin Lipset, et al., Union Democracy (Garden City, New York, 1962), p. 22.

${ }^{38}$ Warren B. Catlin, The Labor Problem in the United States and Great Britain (New York, 1935), pp. 547-548.

${ }^{39}$ Bain and Price, Profiles of Union Growth, pp. 61, 88.

${ }^{40}$ Robert Christie, Empire in Wood: A History of the Carpenters (Ithaca, 1956), pp. 8-11, $62-65,108,156-161$. Collaboration between employers and unions certainly did not eliminate serious conflicts. Employers, however, rarely sought to impose open shops. The major lockouts between 1900 and 1904, for example, were directed against the excesses of union control (such as racketeering and sympathetic strikes) rather then unions and local trade agreements. In the early 1920 s two major open shops offensives against building trades unions did occur, in Chicago and San Francisco. These were led by banking and manufacturing business leaders rather than contractors, however, and Chicago building employers' defection from the movement contributed to its failure in that city. See Selig Perlman and Philip Taft, History of Labor in the United States, 1896-1932 (New York, 1935), pp. 83-93, 504-511; and Christie, Empire in Wood, pp. 158-160.
} 
American building and construction workers enjoyed a level of organization $(55 \%)$ far higher than their British counterparts' $(24 \%) .{ }^{41}$

Finally, where labor costs were high and competition intense some American employers turned to trade agreements to standardize wages and minimize work stoppages - even where the labor process did not make skill decisive. The coal industry is a leading example. When the introduction of mechanical coal mining began in the 1890 s, the United Mine Workers enrolled relatively few coal miners (33,000 in 1898). Beginning in 1897, however, UMW strikes persuaded bituminous (soft) coal operators to collaborate with the union. As their reward for recognizing the union and negotiating interstate pay standards, mining companies removed wages from competition and won no-strike clauses to keep miners at work. By 1904 , the UMW had over 260,000 members, a rate of growth and a union density far exceeding that of the AFL as a whole. ${ }^{42}$

\section{Conclusions}

This examination of industrial relations in the British and American machine trades emphasized how the pace of changes in technology, union growth, and market structure shaped employers' policies. The focus was on management strategies, but the argument has implications for labor organization as well.

The connections between employer policies and unionization are both direct and indirect. The ability of unions to gain members and recognition will be impaired if managers threaten to fire unionists, refuse to bargain with union representatives, and replace striking union members. This is not surprising; neither is it decisive. Employer opposition may be overcome under favorable economic or political conditions, as evidenced by the success of Britain's New Unions after 1910, and the CIO in the late 1930s. On the other hand, while U.S. employees initially may have been less interested in joining unions, more workers tried to organize than succeeded in doing so. Surely some part of their failure came from fear of the consequences - dismissal, blacklisting - which businesses imposed. Less hostile employer policies would have made a difference.

Indirectly, some of the same factors which favored open shop strategies also weakened early labor organizing in the U.S. The stable core of the late

${ }^{41}$ Christie, Empire in Wood, p. 119; and Bain and Price, Profiles of Union Growth, pp. 63, 95.

${ }^{42}$ The anthracite (hard coal) fields were dominated by small numbers of large corporate owners. Competitive pressures were less intense and the virtues of trade agreements less obvious for these employers than they were for operators in bituminous coal. The UMW did win recognition and collective bargaining agreements in the anthracite sector, but their successes before WWI were more limited and came later than in soft coal. See Ramirez, When Workers Fight, chs 1-2; and Green, The World of the Worker, pp. 50-56. 
19th century labor movement in both countries was composed of craft unions. More advanced production methods in the U.S. influenced employer tactics - but also undercut the bargaining power of skilled workers. Industrial concentration diminished the value of trade agreements for employers - but also created strategic problems for union organizers. For example, the ability of employers to shift production among plants made it more difficult for unions to bring effective pressure to bear against a company. By contrast, where technological and market conditions favored a more collaborative approach to labor and, at the same time, increased the leverage of craftsmen, the unions were unusually strong and the impact of the nation's alleged exceptionalism (e.g., American individualism, ethnic cleavages, or luxurious standard of living) apparently negligible.

The economic roots of industrial relations developments have been emphasized here because they seem to account for both the typical outcomes in the U.S. and the occasional departures from American norms. This explanatory strategy has larger implications for the understanding of American exceptionalism. Studies of this phenomenon too often rely on holistic comparisons with Western Europe, and they too often conclude by stressing distinctive features of American society as a whole ("no feudalism", ethnic diversity, etc.). These arguments are undiscriminating, especially when applied to industrial relations as well as to socialism in America. Lipset, for example, explains the belligerance of employers and the weakness of unions by emphasizing the nation's fierce individualism: cultural orientations shared by businessmen and employees alike were hostile to collectivism in labor-management relations. ${ }^{43}$ Steel manufacturers repudiated collectivism in their dealings with labor, consistent with the national culture. Printing employers did not. And though union densities were low among individualistic American machinists, they were high among individualistic American construction workers. The same point can be made against some explanations which highlight America's ethnic diversity: strong unions existed in certain ethnically diverse industries (e.g., coal mining) and weak ones among more homogeneous workers (as in many centers of the machine trades) ${ }^{44}$

The foregoing analysis of industrial relations trends around the turn of the century indicates a need for more systematic comparisons within countries as well as among them. Such comparisons may be used to develop explanations consistent with both average cross-national differences and with internal variations. This methodological strategy will not yield a universally applicable theory. But it will help distinguish the more from the less

${ }^{43}$ Lipset, "North American Labor Movements", pp. 438, 451.

4 An analysis of the divisive effects of ethnicity which is not vulnerable to this criticism is Ira Katznelson, "Working-Class Formation and the State", in Peter Evans et al., (eds), Bringing the State back In (New York, 1985), pp. 257-284. 
decisive factors which, in distinctive national configurations, shaped the early development of employer policies and labor unions. This approach may also enrich our understanding of contemporary industrial relations during a time of renewed change in workplace technology and fluctuating market conditions. 